\title{
Efficient Use of Nitrogen, Gibberellic Acid and Potassium on Canola Production under Sub-tropical Regions
}

\author{
Muhammad Mahran Aslam \\ Nuclear Institute of Agriculture (NIA) \\ Mohammad Aquil Siddiqui ( $\square$ siddiqui_aquil@yahoo.com ) \\ Nuclear Institute of Agriculture (NIA)
}

\section{Research Article}

Keywords: biofortification, exogenous treatments, fertilizers, growth hormone, macronutrient

Posted Date: June 23rd, 2021

DOl: https://doi.org/10.21203/rs.3.rs-626582/v1

License: (c) (i) This work is licensed under a Creative Commons Attribution 4.0 International License.

Read Full License 


\section{Abstract}

The global demand for crop production is rapidly growing due to the continued rise in world population. Crop productivity varies generally with soil nutrient profile and climate. The optimal use of fertilizers might help to attain higher crop yield in canola. To circumvent nutrient imbalance issues in soil, two separate field trials were conducted to determine the best source of nitrogen (ammonium sulfate/ammonium nitrate), foliar application of gibberellic acid $\left(\mathrm{GA}_{3}\right)$ and potassium $(\mathrm{K})$ for the canola yield and yield attributes for four consecutive years (2014 to 2018). Both experiments were carried out in randomized complete block design (RCBD) with three replicates. The nitrogen source in the form of ammonium sulfate $(0,10,20$ and $30 \mathrm{~kg} / \mathrm{ha})$ and ammonium nitrate $(0,50,75$ and $100 \mathrm{~kg} / \mathrm{ha})$ was applied in the rhizosphere. In another experiment, the canola crop was sprayed with four level of gibberellic acid $\left(\mathrm{GA}_{3} ; 0,10,15,30 \mathrm{~g} / \mathrm{ha}\right)$ and potassium $(\mathrm{K} ; 0,2.5,3.5,6 \mathrm{~g} / \mathrm{ha})$ separately or in combination by using hydraulic spryer. The analysis showed that fertilization with nitrogen in the form of ammonium nitrate $(100 \mathrm{~kg} / \mathrm{ha})$ and ammonium sulfate $(30 \mathrm{~kg} / \mathrm{ha})$ had a positive effect on the plant height, number of branches, fruiting zone, seed yield per plant, seed yield per hectare of canola except oil percentage. Moreover, canola plants displayed a significant improvement on all studied features with high dosses of $\mathrm{GA}_{3}(30 \mathrm{~g} / \mathrm{ha})$ and $\mathrm{K}(6 \mathrm{~g} / \mathrm{ha})$ individualy and in combined form. In a nutshell, compared to both source of nitrogen, ammonium nitrate was more efficient and readily available source of nitrogen. Gibbrellic acid being a natural growth elicitor and potassium as a micronutrient serve as potential source to improve yield and to mange nutrient profile of canola.

\section{Introduction}

For several years now, Arid and semi-arid areas located in certain third world countries have been facing massive shortage of edible oils which was met through imports in large quantities from other countries ${ }^{1}$. As a result, efforts aiming at reducing the imbalance between the production and consumption for edible oils have been made by under-developed countries. In this context, oil seed crops seemed to be an accurate option for these countries. Among these crops, canola appeared as a potential candidate for the domestic edible oil production ${ }^{2}$. This could be explained by to the low content of erucic acid and glucosinolates in oil and seed cake, respectively ${ }^{3}$. Moreover, canola crop can survive under diverse environmental conditions due to a wide range of adaptability ${ }^{4}$. However, mismanagement and highly imbalanced application of micro and macronutrients found to be reducing the yield of canola crop, therefore, nutrients management strategies for optimizing the canola production are highly required ${ }^{5}$

Balanced fertilizer application influence the crop yield, quality and the soil productivity ${ }^{6}$. The adequate nitrogen supply is important in order to boost up the canola productivity and it holds a key role in plant tissue growth and development. Plus, it represents a part of chlorophyll, nucleotides, protein, and amino acids formation which directly affect the quality and quantitative traits of the crop. Other factors such as Soil profile, texture, and moisture content fluctuation at various critical stages of growth and development of canola may influence the nitrogen use efficiency on canola crop. Actually, this kind of crop can very 
responsive to fertilizer application, especially nitrogen which significantly impacts the plant height, number of branches/plant, number of flower/plant, number of pods/ plant and their weights, and seed yield/ ha. It also effects of the leaf area (LA) development and LA duration after flowering in canola crop 7,8

Many natural and artificial plant regulators may be used with the aim of controlling the developmental process from germination to post-harvest preservation of crop plants and subsequently, optimizing their production ${ }^{9}$. Among these fertilizers, gibberellic acid $\left(\mathrm{GA}_{3}\right)$ is obviously a key regulator product for plantgrowth and other physiological mechanisms. It can stimulates the root and stem elongation, seed germination ,break dormancy, leaf expansion, fruit senescence, and flowering ${ }^{10}$. Moreover, GAs may influence the metabolic pathways including nitrogen metabolism, chlorophyll production and degradation, nitrogen redistribution, and translocation of assimilates ${ }^{11}$. It can also induces the expression of several hydrolytic enzymes involved in the conversion of starch to sugar which ultimately influence the plant growth at vegetative and reproductive stages ${ }^{12}$, plant signaling mechanisms, gene expression, and plant morphology and physiology ${ }^{13,14}$.

Besides nitrogen and phosphorus fertilizers, potassium ( $\mathrm{K}$ ) found to be influencing the seed oil content percentage, yield and yield-contributing traits of the canola crop ${ }^{15,16} \mathrm{~K}$ is very important fertilizer which is involved in photosynthesis, regulation of stomata, control of the ionic balance, translocation of photosynthates, protein synthesis, enzymatic activities, and many other physiological and biochemical processes ${ }^{17,18}$. Therefore, $\mathrm{K}$ is considered as primary osmoticum that plays an important role at maintaining the low water potential in plant tissue and also impacts the plant growth and development.

For plant breeders, the efficient use of nutrients from the soil by the crop plants is a promising characteristic. Some plants may produce high yields with minimal inputs ${ }^{14,18}$. Many studies showed that significant variation exists among various genotypes of canola regarding efficient use of potassium ${ }^{19}$.

Keeping in view the possible outcomes of efficient use of $\mathrm{K}$ and GA, the current study evaluates canola genotype (Surhan-2012) for four consecutive years for these traits. Hence, current manuscript demonstrated the influence of foliar application of $\mathrm{GA}_{3}$ and $\mathrm{K}$ separately, or in combination in canola. This study carries immense importance as a reference for the impact of these two important nutrients on canola production and the multi-year screening of Surhan-2012 in this context.

\section{Material And Methods}

\section{Experimental Design}

The field experiment was conducted at the farm of Nuclear Institute of Agriculture (NIA), Tando Jam, Sind, Pakistan ( $31^{\circ} 25^{\prime} 0^{\prime \prime}$ North, $73^{\circ} 5^{\prime} 0^{\prime \prime}$ East) during the four seasons of 2014-2018. Data were collected under a randomized Complete Block Design (RCBD) with three replications per block. 
The canola seeds were collected from nuclear institute of Agriculture (NIA) TandoJam and sown. The plants thinned after 15-20 days of germination for the purposes of maintaining long distance dispersal of plants. All the recommended agronomic and cultural practices that govern the production of the crop were applied efficiently during the plant growth cycle ${ }^{20}$.

\section{Application of ammonium sulfate $\left[\left(\mathrm{NH}_{4}\right)_{2} \mathrm{SO}_{4}\right]$ and ammonium nitrate $\left[\left(\mathrm{NH}_{4}\right) \mathrm{NO}_{3}\right]$ as Nitrogen supplements}

The four levels of ammonium sulfate $(0,10,20$ and $30 \mathrm{~kg} / \mathrm{ha})$ and ammonium nitrate $(0,50,75$ and 100 $\mathrm{kg} / \mathrm{ha}$ ) were used as nitrogen source. Both nitrogen fertilizers were applied in two split doses; the first dose was applied after three weeks of crop sowing whereas the second was undertaken after seven weeks of sowing. One square meter $\left(\mathrm{m}^{2}\right)$ area of plants was chosen randomly from each plot for harvesting during four seasons of 2014-18. The agronomic parameters of crops were computed from the plant height $(\mathrm{cm})$, number of branches/plant, fruiting zone length $(\mathrm{cm})$, seed yield/plant $(\mathrm{g})$, seed yield/ha $(\mathrm{kg})$. the differences of oil content (\%) of canola seeds were recorded, pooled and statistically analyzed in order to evaluate the effect of different sources/doses of nitrogen on the agronomic characters and traits of canola ${ }^{16}$.

\section{The effect of potassium nitrate and Gibberellic Acid on canola seed germination}

Ten different combinations (Table 1) of $\mathrm{K}_{\text {and }} \mathrm{GA}_{3}$ were applied as foliar spray. The experiment was carried out using a randomized complete block design (RCBD) with three replications.

Before the foliar application, $\mathrm{GA}_{3}$ was dissolved in ethanol and mixed with water. Various dilutions were then made in order to obtain solutions with several concentrations. The different combinations of $\mathrm{GA}_{3}$ and potassium were sprayed after one month of sowing. The treatments were applied three times at one week intervals and the control plants were sprayed with distilled water only. One $\mathrm{m}^{2}$ area of plants was chosen randomly from each plot at harvesting time during four seasons (2014-18). The data of agronomic parameters including Plant height $(\mathrm{cm})$, number of branches/plant, fruiting zone length $(\mathrm{cm})$, seed yield/plant $(\mathrm{g})$, seed yield/ha $(\mathrm{kg})$ and oil content percentage have been recorded according to the protocol reported by A.O.A.C in 1980. Subsequently, the recorded data were analyzed using analysis of variance (ANOVA) combined with HSD (Steel et al., 1997). Tukey's test was also used to determine the significant difference between the treatments with the help of statistical software SAS (version 9.4) and finally calculation of the Cost-benefit ratio.

\section{Results And Discussion}

\section{Effect of ammonium sulfate $\left(\mathrm{NH}_{4}\right)_{2} \mathrm{SO}_{4}$ as nitrogen source on crop production}


The statistical analyses performed during all four seasons showed significant differences on all studied features (Table 2). Results obtained in the current investigation suggest that ammounium sulfate $\left[\left(\mathrm{NH}_{4}\right)_{2} \mathrm{SO}_{4}\right]$ impacts positively on plant height, number of branches per plant, fruiting zone length, seed yield per plant, seed yield per hectare and oil percentage with the increased levels of nitrogen (Table 2). The maximum plant height, number of branches per plant, fruiting zone length, seed yield per plant, seed yield per hectare and oil contents were recorded in the presence of $30 \mathrm{~kg} / \mathrm{ha}$ ammonium sulfate compared to control plants of canola. Correlation analysis was performed in order to evaluate the agronomic characteristics after the ammonuim sulfate treatment and it was found that signficant results have been achieved with respect to the ammounium sulfate treatments and plant height (0.998), number of branches per plant (0.953), fruiting zone length (0.987), seed yield per plant (0.994), seed yield per hactare (0.994) (Table 3). Another important factor that must be taken into account is the Sulfur element since it plays an important role in the synthesis of proteins which in turn affects the oil contents in canola seeds ${ }^{21}$. Hence, the balanced application of $\mathrm{S}$ and $\mathrm{N}$ is vital with the objective of further improving the canola seeds quality and production ${ }^{21}$. Karamanoset al. ${ }^{22}$ suggested that the optimal ratio of $\mathrm{N}: \mathrm{S}$ ranging from 7:1 to 5:1 can maximize canola production. In fact, a study conducted by Brennan and M.D.A, 2008 and proven that the canola production can be extremely limited in case of sulfur deficiency in soil ${ }^{23}$. The supply of artificial sulfur promotes the nitrogen uptake efficiency of canola production and consequently elevates the level of protein in leaves: this will definitely enhance the crop productivity and yield ${ }^{24}$.

Our results are in agreement with those reported by Chienet al. ${ }^{25}$ in which the plant height and number of branches were boosted when higher rates of ammonium sulfate were applied. Other researchers have reported similar results in which they have indicated that the 1000-seed weight increases proportionately with sulfur and nitrogen levels ${ }^{26}$. Others have suggested that biological yield increases significantly when increasing the nitrogen and sulfur rates ${ }^{27}$.

\section{Influence of $\mathrm{NH}_{4} \mathrm{NO}_{3}$ as nitrogen source on canola plants}

The ammonium nitrate treatment has considerably influenced the crop's agronomic and quality traits compared to the control canola plants in th field. The recorded results including the maximum plant height $(194 \mathrm{~cm})$, number of branches per plant (9), fruiting zone length $(156.2 \mathrm{~mm})$, seed yield per plant $(42.4 \mathrm{~g})$ and seed yield per hectare $(1007.2 \mathrm{~kg})$ showed an increase in all of the aforementioned agronomic attributes (Table 2), except for the oil percentage that has decreased by 0.8 percentage point when $\mathrm{NH}_{4} \mathrm{NO}_{3}(100 \mathrm{~kg} / \mathrm{ha}$ ) treatment was applied (Table 2). The correlation coefficient between the ammonium nitrate rates and agronomic characteristics have indicated that the morphological traits were positively affected when nitrogen nutrient was added in a form of $\mathrm{NH}_{4} \mathrm{NO}_{3}$. A high positive correlation was also observed between yield attributes and ammonium nitrate rates for plant height (0.987), number of branches per plant (0.887), fruiting zone length (0.957), seed yield per plant (0.953), and seed yield per hactare (0.953), while negative correlation with oil contents was detected (Table 3). From these findings it can be concluded that a nutrient deficiency (nitrogen) can severely hampers canola productivity 28,29 . Furthermore, the canola yields can be enhanced by a better management of nitrogen at the optimum 
growth stages of canola ${ }^{2,16}$. Nitrogen is an essential plant nutrient that simulates its meristematic activity, cell elongation, and elevates the photosynthesis of canola. These factors will ultimately boost growth and yield of the canola plant ${ }^{30}$. A pervious study published by Khan, S., et al, 2018, they haves demonstrated that 3.8qt/ha (Quintal/hectare) oil yield was achieved through rigorous application of 60 $\mathrm{kg}$ of nitrogen per hectare ${ }^{31}$. Similar findings have been made in other studies highlighting the importance of nitrogen supplementation in the refinement of the rapeseed yields in diverse agro- climatic conditions $^{32}$.

As far as we know, Nitrogen has strongly and significantly correlated with the seed yield per hectare, plant height, number of branches per plant, fruiting zone length, and number of seed per plant, in addition to the enhancement of the number of pods per seed, 1000 seed weight, biological yield, seed yield, and oil yield ${ }^{27,32}$. On this basis, it can be concluded that the canola production depends on the selection of the correct dose, source, and timing of nitrogen fertilizer application. Unbalanced application of nitrogen fertilizer may adversely affect the canola production ${ }^{6}$. The source of nitrogen fertilizer may also change the plant $\mathrm{N}$ uptake and soil $\mathrm{N}$ availability and hence impacting the ultimate canola productivity ${ }^{33}$. In our experiments, two sources of nitrogen were tested and compared one with another. The subsequent results showed that ammonium nitrate had significantly contributed to the enhancement of canola production comparing to the ammonium sulfate ${ }^{34}$. It has been reported elsewhere that the application of ammonium sulfate reduces the $\mathrm{pH}$ of the soil as well as dissolution of many other nutrients resulting in negative impacts on plant growth and development compared to ammonium nitrate ${ }^{35}$.

\section{Effect of foliar application of Gibberellic acid and potassium fertilizer on canola yield and yield components}

The influence of various treatments related to the application of gibberellic acid and potassium fertilizer were also studied in accordance with the yield parameters of canola. The results of the present study provide evidence that all the agronomic traits and oil percentage tend to increase with increasing levels of foliar application of $\mathrm{K}$ and $\mathrm{GA}_{3}$ solely or combined in comparaison with the unsprayed plants. $\mathrm{A}$ significant increase was recorded using different treatements of GA3 and $\mathrm{K}$ in plant height, number of branches per plant, fruiting zone length, seed yield per plant, seed yield/ha and seed oil percentage compared to control $\left(\mathrm{T}_{1}-\mathrm{T}_{10}\right)$.

The measurement values of plant-height in all of the treatments were higher than the control plant during a four-year period (2014 to 2018). Significant differences were also observed among the treatments $(F=81.913 ; p \leq 0.0000, F=99.79 ; p \leq 0.0000, F=86.782 ; p \leq 0.0000$, and $F=101.34 ; p \leq 0.0000)$ during all seasons (Table 4). The maximum plant-height was reported when combined $\mathrm{GA}_{3}(30 \mathrm{~kg} / \mathrm{ha})$ and $\mathrm{K}(6$ $\mathrm{g} / \mathrm{m}^{2}$ ) ( $\mathrm{T}_{10}$ followed by $\mathrm{T}_{9}, \mathrm{~T}_{8}$ and so on) (Table 4) were applied. However, both $\mathrm{T}_{4}\left(\mathrm{GA}_{3} 0\right.$ and $\mathrm{K} 6.0$ ) and $\mathrm{T}_{8}\left(\mathrm{GA}_{3} 10 \mathrm{~kg} / \mathrm{ha}\right.$ and $\left.\mathrm{K} 2.0 \mathrm{~g} / \mathrm{m}^{2}\right)$ showed an almost insignificant variation in the plant-height meseaurements compared to other treatments. 
The foliar application of $\mathrm{K}$ and $\mathrm{GA}_{3}$ significantly affected the number of branches per canola plant comparing to the control one $\left(T_{1}\right)$. The highest number of branches per plant were recorded in $T_{10}$ $\left(30 \mathrm{GA}_{3} \mathrm{~g} / \mathrm{ha}+6.0 \mathrm{~g} / \mathrm{m}^{2} \mathrm{~K}\right)$ which appeared to have the same trend as that reported for canola plant-height measurements (Table 5). A considerable rise in the fruiting zone length $(\mathrm{cm})$ was also observed when combined foliar applications were applied $\left(T_{10}\right)$. The significant differences among the treatments $(F=101.814 ; p \leq 0.0000, F=123.32 ; p \leq 0.0000, F=126.62 ; p \leq 0.0000$ and $F=122.4 ; p \leq 0.0000)$ were also noted for over four years of the study (Table 6). As

Another agronomic trait was affected when foliar applications of $\mathrm{K}$ and $\mathrm{GA}_{3}$ were applied (individually or combined) is the number of seeds per plant: it was found that canola plants produce more number of seeds per plant when combined $\mathrm{GA}_{3}$ and $\mathrm{K}$ were applied $\left(T_{10}\right)$ during the four seasons of 2014-2018 (Table 7). This parameter seemed to be improved immeasurably in all treatments $\left(T_{2}-T_{10}\right)$ compared to the control plant $\left(T_{1}\right)$. Therefore, it can be concluded that improvement of this agronomic parameter can be successfully attained when increased rates of the foliar (K and GA3) were applied.

Since seed yield ha-1 is considered as the main interest for canola breeders, higher rates of the foliar ( $\mathrm{K}$ and $\mathrm{GA}_{3}$ ) were applied (individually or combined) with respect to non-sprayed plants $\left(\mathrm{T}_{1}\right)$; the obtained results of this investigation indicate that high seed yield occurs in all treatments $\left(T_{2}-T_{10}\right)$, particularly, when increased rates of the foliar were applicable.

This important rise in seed yield/ha (883.2) was recorded with $30 \mathrm{~kg} / \mathrm{ha} \mathrm{GA}$ and $6 \mathrm{~g} / \mathrm{m}^{2} \mathrm{~K}$ foliar application $\left(T_{10}\right)$. The significant differences were also detected among the following treatments $(F=44.576 ; p \leq 0.0000, F=49.903 ; p \leq 0.0000, F=48.765 ; p \leq 0.0000$ and $F=51.273 ; p \leq 0.0000)$ applied during the experimental period (Table 8).

The changes in oil percentages, in response to $\mathrm{K}$ and $\mathrm{GA}_{3}$ application were also investigated. The highest oil percentage was observed at the $T_{10}$ treatment followed by $T_{3}$ and $T_{5}$ during the four cropping seasons of 2014-18 (Table 9).

In view of the aforementioned findings, it can be concluded that combined form of $\mathrm{GA}_{3}$ and $\mathrm{K}\left(\mathrm{T}_{10}\right)$ presents a potential strategy to enhance growth performance of canola. The promoting effect of gibberellic acid and potassium treatments contribute to the metabolic and other physiological processes leading to better crop yields. Interestingly, for the majority of the studied traits, the K application $\left(T_{4}\right)$ acts similarly and almost insignificantly to the combined application $\left(T_{8}\right)$ of $K\left(3.5 \mathrm{~g} / \mathrm{m}^{2}\right)$ and $G A_{3}(15 \mathrm{~g} / \mathrm{ha})$, this could be attributed to the key role of $\mathrm{K}$ in improving canola yields (Table 4-9).

$\mathrm{GA}_{3}$ and $\mathrm{K}$ fertilizer application is necessary to increase the vegetative and reproductive growth of canola plant ${ }^{36}$. These fertilizers could be involved in improving defence mechanisms of canola plant which may consequenlty affect the seed yield. Similar results have been reported using these same treatments on sesame plant ${ }^{28}$. Likewise, foliar application of potassium and gibberelic acid alone or in combination 
incerases the plant vegetative and reproductive growth of the plant resulting in the enhancement of the yield per unit ${ }^{37}$. In fact, in a study reported by Imran and A.A. Khan, 2017, the application of $\mathrm{K}$ fertilizer not only enhances the yield per unit, fresh nut and karnel dry mass (spliting percentage), it also reduces the blank percentage ${ }^{38}$. It was also observed that in absence of gibberellic acid applications, the blank percentage and spliting percentage could be ameliorated ${ }^{39}$.

Jan et al (2019) reported that high concentrations of potassium K and Zing Zn after the simultaneous foliar applications of $\mathrm{GA}_{3}$ and $\mathrm{K}$ separately or in combination could be found in canola plant leaves ${ }^{40}$. The evidences of this study suggest that the interactive effects of $\mathrm{GA}_{3}$ and $\mathrm{K}$ can be employed in the aim of improving morphological aspects and yield attributes of canola. It can also be expected that these interactive effects may elevate the plant resistance against various biotic and abiotic stresses, carbohydrate translocation, and the photosynthesis process ${ }^{39}$. Khan et al (2019) also mentioned that these fertlizers $\left(\mathrm{GA}_{3}\right.$ and $\mathrm{K}$ ) might strengthen the defence mechanism of the plant which ultimately impacts the plant growth and yield ${ }^{41,42}$. In short, with appropriate application of nitrogen fertilizers, $\mathrm{GA}_{3}$, and $\mathrm{K}$, canola yeilds can be substantially improved.

\section{Ethic statements}

This study does not involve any wild or endangered species of plants. Moreover, it does not encompass the collection of any new plant material. The study is only related to the field performance of a canola genotype under different growth treatments. The seeds of canola were collected from nuclear institute of Agriculture (NIA) tandojam. The evaluated genotype is a cultivated species and is a released variety in Pakistan. The experiment was conducted in line with institutional and national policies.

\section{Conclusion}

Nitrogen is a an essentiel nutrient for the metabolic function and production process of the canola plant or any other plant. Therefore, the canola yields can be monitored with the application of nitrogen fertilizers pertaining to different sources and proportions. The optimum levels of nitrogen fertilizer were found to be $30 \mathrm{~kg} / \mathrm{ha}$ ammonium sulfate and $100 \mathrm{~kg} / \mathrm{ha}$ ammonium nitrate. These data have been obtained according to the of agronomic yields of a four-year study (2014-18). Another fact to consider is that Ammonium nitrate $\left(\mathrm{NH}_{4} \mathrm{NO}_{3}\right)$ is more efficient and readily available source of nitrogen compared to ammonium sulfate $\left[(\mathrm{NH} 4)_{2} \mathrm{NO}_{3}\right]$. This study has recommended the optimum value and source in subtropical region of the world. On the contrary, gibberellic acid and potassium influence the plant growth and its development, enable the plant to survive in nutrient deficient soil and increase the yield in the four growing seasons (2014-18). It is suggested that canola plant illustrated maximum potential of yield at high dose of $\mathrm{GA}_{3}(30 \mathrm{~g} / \mathrm{ha})$ andK $\left(6.0 \mathrm{~g} / \mathrm{m}^{2}\right)$ alone or in combination.

\section{References}


1. Odhiambo, G. O. Water scarcity in the Arabian Peninsula and socio-economic implications. Applied Water Science 7, 2479-2492, doi:10.1007/s13201-016-0440-1 (2017).

2. Hu, Q. et al. Rapeseed research and production in China. The Crop Journal 5, 127-135, doi:https://doi.org/10.1016/j.cj.2016.06.005 (2017).

3. Mitrović, P. M. et al. White Mustard (Sinapis alba L.) Oil in Biodiesel Production: A Review. Frontiers in plant science 11, 299-299, doi:10.3389/fpls.2020.00299 (2020).

4. Raza, A. et al. Impact of Climate Change on Crops Adaptation and Strategies to Tackle Its Outcome: A Review. Plants (Basel) 8, 34, doi:10.3390/plants8020034 (2019).

5. Selim, M. M. Introduction to the Integrated Nutrient Management Strategies and Their Contribution to Yield and Soil Properties. International Journal of Agronomy 2020, 2821678, doi:10.1155/2020/2821678 (2020).

6. Bindraban, P. S., Dimkpa, C., Nagarajan, L., Roy, A. \& Rabbinge, R. Revisiting fertilisers and fertilisation strategies for improved nutrient uptake by plants. Biology and Fertility of Soils 51, 897-911, doi:10.1007/s00374-015-1039-7 (2015).

7. Shirazi, S. M., Yusop, Z., Zardari, N. H. \& Ismail, Z. Effect of Irrigation Regimes and Nitrogen Levels on the Growth and Yield of Wheat. Advances in Agriculture 2014, 250874, doi:10.1155/2014/250874 (2014).

8. Manik, S. M. N. et al. Soil and Crop Management Practices to Minimize the Impact of Waterlogging on Crop Productivity. Frontiers in plant science 10, 140-140, doi:10.3389/fpls.2019.00140 (2019).

9. Iqbal, N. et al. Ethylene Role in Plant Growth, Development and Senescence: Interaction with Other Phytohormones. Frontiers in plant science 8, 475-475, doi:10.3389/fpls.2017.00475 (2017).

10. Vishal, B. \& Kumar, P. P. Regulation of Seed Germination and Abiotic Stresses by Gibberellins and Abscisic Acid. Frontiers in Plant Science 9, doi:10.3389/fpls.2018.00838 (2018).

11. Khan, N. A., Mir, R., Khan, M., Javid, S. \& Samiullah. Effects of gibberellic acid spray on nitrogen yield efficiency of mustard grown with different nitrogen levels. Plant Growth Regulation 38, 243-247, doi:10.1023/A:1021523707239 (2002).

12. Gupta, R. \& Chakrabarty, S. K. Gibberellic acid in plant: still a mystery unresolved. Plant Signal Behav 8, e25504, doi:10.4161/psb.25504 (2013).

13. Tiwari, S., Lata, C., Chauhan, P. S., Prasad, V. \& Prasad, M. A Functional Genomic Perspective on Drought Signalling and its Crosstalk with Phytohormone-mediated Signalling Pathways in Plants. Curr Genomics 18, 469-482, doi:10.2174/1389202918666170605083319 (2017).

14. Colebrook, E. H., Thomas, S. G., Phillips, A. L. \& Hedden, P. The role of gibberellin signalling in plant responses to abiotic stress. The Journal of Experimental Biology 217, 67, doi:10.1242/jeb.089938 (2014).

15. Ragel, P., Raddatz, N., Leidi, E. O., Quintero, F. J. \& Pardo, J. M. Regulation of K(+) Nutrition in Plants. Frontiers in plant science 10, 281-281, doi:10.3389/fpls.2019.00281 (2019). 
16. Khan, S. et al. Alteration in yield and oil quality traits of winter rapeseed by lodging at different planting density and nitrogen rates. Sci Rep 8, 634-634, doi:10.1038/s41598-017-18734-8 (2018).

17. Tränkner, M., Tavakol, E. \& Jákli, B. Functioning of potassium and magnesium in photosynthesis, photosynthate translocation and photoprotection. Physiologia Plantarum 163, 414-431, doi:10.1111/ppl.12747 (2018).

18. Koch, M., Naumann, M., Pawelzik, E., Gransee, A. \& Thiel, H. The Importance of Nutrient Management for Potato Production Part I: Plant Nutrition and Yield. Potato Research 63, 97-119, doi:10.1007/s11540-019-09431-2 (2020).

19. Bahrami-Rad, S. \& Hajiboland, R. Effect of potassium application in drought-stressed tobacco (Nicotiana rustica L.) plants: Comparison of root with foliar application. Annals of Agricultural Sciences 62, 121-130, doi:https://doi.org/10.1016/j.aoas.2017.08.001 (2017).

20. Porter, M. J. et al. Winter canola response to soil and fertilizer nitrogen in semiarid Mediterranean conditions. Agronomy Journal 112, 801-814, doi:https://doi.org/10.1002/agj2.20119 (2020).

21. Poisson, E. et al. Seed Yield Components and Seed Quality of Oilseed Rape Are Impacted by Sulfur Fertilization and Its Interactions With Nitrogen Fertilization. Frontiers in Plant Science 10, doi:10.3389/fpls.2019.00458 (2019).

22. Karamanos, R. E., Goh, T. B. \& Poisson, D. P. Nitrogen, Phosphorus, and Sulfur Fertility of Hybrid Canola. Journal of Plant Nutrition 28, 1145-1161, doi:10.1081/PLN-200063138 (2005).

23. Brennan, R. F. \& Bolland, M. D. A. Significant Nitrogen by Sulfur Interactions Occurred for Canola Grain Production and Oil Concentration in Grain on Sandy Soils in the Mediterranean-Type Climate of Southwestern Australia. Journal of Plant Nutrition 31, 1174-1187, doi:10.1080/01904160802134459 (2008).

24. Ahmad, G., Jan, A., Arif, M., Jan, M. T. \& Khattak, R. A. Influence of nitrogen and sulfur fertilization on quality of canola (Brassica napus L.) under rainfed conditions. J Zhejiang Univ Sci B 8, 731-737, doi:10.1631/jzus.2007.B0731 (2007).

25. Chien, S. H. et al. Agronomic Effectiveness of Granular Nitrogen/Phosphorus Fertilizers Containing Elemental Sulfur with and without Ammonium Sulfate: A Review. Agronomy Journal 108, 1203-1213, doi:10.2134/agronj2015.0276 (2016).

26. Bouranis, D. L., Gasparatos, D., Zechmann, B., Bouranis, L. D. \& Chorianopoulou, S. N. The Effect of Granular Commercial Fertilizers Containing Elemental Sulfur on Wheat Yield under Mediterranean Conditions. Plants (Basel) 8, 2, doi:10.3390/plants8010002 (2018).

27. Geng, Y., Cao, G., Wang, L. \& Wang, S. Effects of equal chemical fertilizer substitutions with organic manure on yield, dry matter, and nitrogen uptake of spring maize and soil nitrogen distribution. PLoS One 14, e0219512-e0219512, doi:10.1371/journal.pone.0219512 (2019).

28. Anjum, N. A. et al. Improving growth and productivity of Oleiferous Brassicas under changing environment: significance of nitrogen and sulphur nutrition, and underlying mechanisms. ScientificWorldJournal 2012, 657808-657808, doi:10.1100/2012/657808 (2012). 
29. Khan, A. et al. Nitrogen fertility and abiotic stresses management in cotton crop: a review. Environmental Science and Pollution Research 24, 14551-14566, doi:10.1007/s11356-017-8920-x (2017).

30. Li, M. et al. Leaf Senescence, Root Morphology, and Seed Yield of Winter Oilseed Rape (<i>Brassica napus</i> L.) at Varying Plant Densities. BioMed Research International 2017, 8581072, doi:10.1155/2017/8581072 (2017).

31. Khan, S. et al. Alteration in yield and oil quality traits of winter rapeseed by lodging at different planting density and nitrogen rates. Sci Rep 8, 634, doi:10.1038/s41598-017-18734-8 (2018).

32. Albert, B. et al. Nitrogen availability impacts oilseed rape (Brassica napus L.) plant water status and proline production efficiency under water-limited conditions. Planta 236, 659-676, doi:10.1007/s00425-012-1636-8 (2012).

33. Amanullah, Iqbal, A., Ali, A., Fahad, S. \& Parmar, B. Nitrogen Source and Rate Management Improve Maize Productivity of Smallholders under Semiarid Climates. Frontiers in plant science 7, 1773-1773, doi:10.3389/fpls.2016.01773 (2016).

34. Anjum, N. A. et al. Improving Growth and Productivity of Oleiferous Brassicas under Changing Environment: Significance of Nitrogen and Sulphur Nutrition, and Underlying Mechanisms. The Scientific World Journal 2012, 657808, doi:10.1100/2012/657808 (2012).

35. Neina, D. The Role of Soil pH in Plant Nutrition and Soil Remediation. Applied and Environmental Soil Science 2019, 5794869, doi:10.1155/2019/5794869 (2019).

36. Wang, Z.-H., Li, S.-X. \& Malhi, S. Effects of fertilization and other agronomic measures on nutritional quality of crops. Journal of the Science of Food and Agriculture 88, 7-23, doi:10.1002/jsfa.3084 (2008).

37. Ullah, S. et al. Interactive effect of gibberellic acid and NPK fertilizer combinations on ramie yield and bast fibre quality. Sci Rep 7, 10647-10647, doi:10.1038/s41598-017-09584-5 (2017).

38. Imran \& Khan, A. A. Canola yield and quality enhanced with sulphur fertilization. Russian Agricultural Sciences 43, 113-119, doi:10.3103/S1068367417020100 (2017).

39. Chauhan, A. et al. Influence of gibberellic acid and different salt concentrations on germination percentage and physiological parameters of oat cultivars. Saudi J Biol Sci 26, 1298-1304, doi:10.1016/j.sjbs.2019.04.014 (2019).

40. Jan, A. U., Shah, A. \& Hadi, F. Role of potassium, zinc and gibberellic acid in increasing drought stress tolerance in sunflower (helianthus annuus I). Pakistan Journal of Botany 51, 809-815 (2019).

41. Khan, N. et al. Comparative Physiological and Metabolic Analysis Reveals a Complex Mechanism Involved in Drought Tolerance in Chickpea (Cicer arietinum L.) Induced by PGPR and PGRs. Sci Rep 9 , 2097, doi:10.1038/s41598-019-38702-8 (2019).

42. Waqas, M. A. et al. Potential Mechanisms of Abiotic Stress Tolerance in Crop Plants Induced by Thiourea. Frontiers in plant science 10, 1336-1336, doi:10.3389/fpls.2019.01336 (2019).

\section{Tables}


Table 1: Treatment levels of Potassium-K Fertilizer and Gibberellic acid on Canola Production

\begin{tabular}{|lll|}
\hline Treatments & Potassium-K $\left(\mathrm{g} / \mathrm{m}^{2}\right)$ & Gibberellic acid $(\mathrm{g} / \mathrm{ha})$ \\
\hline T1 & 0 (Control) & 0 (Control) \\
\hline T2 & 2.0 & 0 \\
T3 & 3.5 & 0 \\
\hline T4 & 6.0 & 0 \\
\hline T5 & 0 & 10 \\
T6 & 0 & 15 \\
\hline T7 & 0 & 30 \\
\hline T8 & 2.0 & 10 \\
\hline T9 & 3.5 & 15 \\
\hline T10 & 6.0 & 30 \\
\hline
\end{tabular}


Table 2: Impact of rate and source of Nitrogen on the mean yield and yeild attribute during 2014-18

Nitrogen

Ammonium Sulfate

\begin{tabular}{|c|c|c|c|c|c|c|}
\hline Treatments & $\begin{array}{l}\text { Plant } \\
\text { Height }\end{array}$ & $\begin{array}{l}\text { No. of } \\
\text { branches }\end{array}$ & $\begin{array}{l}\text { Fruiting } \\
\text { Zone }\end{array}$ & $\begin{array}{l}\text { Seed } \\
\text { yield/Plant }\end{array}$ & $\begin{array}{l}\text { Seed } \\
\text { yield/fed. }\end{array}$ & $\begin{array}{l}\text { Oil } \\
\text { percentage }\end{array}$ \\
\hline \multirow[t]{2}{*}{0} & $141.5 \mathrm{bc}$ & $5.5 \mathrm{a}$ & $109.1 \mathrm{ac}$ & $29.9 \mathrm{ad}$ & $725.7 \mathrm{a}$ & $43.02 \mathrm{a}$ \\
\hline & * & * & * & ** & ** & * \\
\hline 10 kg/fed. & $150.7 \mathrm{~b}$ & $5.7 \mathrm{a}$ & $116.4 \mathrm{a}$ & $32.8 \mathrm{a}$ & $788.1 \mathrm{~b}$ & $42.5 \mathrm{a}$ \\
\hline 20 kg/fed. & $160.1 \mathrm{ab}$ & $6.4 \mathrm{~b}$ & $121.7 \mathrm{a}$ & $35.2 \mathrm{~b}$ & $833.7 \mathrm{c}$ & $43.5 \mathrm{~b}$ \\
\hline 30 kg/fed. & $168.4 \mathrm{a}$ & $7.1 \mathrm{c}$ & $131.5 b$ & $37.8 \mathrm{c}$ & $908.2 \mathrm{~d}$ & $43.8 \mathrm{~b}$ \\
\hline \multicolumn{7}{|c|}{ Ammonium Nitrate } \\
\hline \multirow[t]{2}{*}{0} & $141.2 \mathrm{~d}$ & $5.3 \mathrm{~cd}$ & $110.4 d$ & $30.2 \mathrm{c}$ & $729.0 \mathrm{c}$ & $41.9 \mathrm{~b}$ \\
\hline & $\star *$ & * & $\star *$ & $\star *$ & $\star \star$ & * \\
\hline $50 \mathrm{~kg} / \mathrm{fed}$ & $157.1 \mathrm{c}$ & $6.3 \mathrm{bc}$ & $124.4 \mathrm{C}$ & $34.6 \mathrm{~b}$ & $830.4 \mathrm{~b}$ & $45.01 \mathrm{a}$ \\
\hline 75 kg/fed. & $169.9 \mathrm{~b}$ & $7.1 \mathrm{~b}$ & $133.0 \mathrm{~b}$ & $36.1 \mathrm{~b}$ & $861.4 \mathrm{~b}$ & $40.37 c$ \\
\hline $\begin{array}{l}100 \\
\mathrm{~kg} / \text { fed. }\end{array}$ & $194.0 \mathrm{a}$ & 9 a & $156.2 \mathrm{a}$ & $42.4 \mathrm{a}$ & $1007.2 \mathrm{a}$ & $38.19 \mathrm{c}$ \\
\hline
\end{tabular}

Value within the column with the same letter are not significantly different (Tukey, HSD; p0.05), ${ }^{\star}$ P0.01 according to least significant difference (LSD) test. 


\begin{tabular}{|c|c|c|c|}
\hline \multicolumn{4}{|c|}{ Ammunium Sulfate } \\
\hline Correlation & $R$ value & SE & $P(r=0)$ \\
\hline Plant Height & 0.998 & 0.020 & $0.0000(\star \star \star)$ \\
\hline No. of branches & 0.953 & 0.029 & $0.0000{ }^{(\star \star \star)}$ \\
\hline Fruiting Zone & 0.987 & 0.039 & $\left.0.0000{ }^{(* \star *}\right)$ \\
\hline Seed yield/plant & 0.994 & 0.034 & $0.0000(\star \star \star)$ \\
\hline Seed yield/fed. & 0.994 & 0.034 & $0.0000{ }^{(\star \star \star)}$ \\
\hline Oil Percentage & 0.986 & 0.051 & $0.0000{ }^{(\star \star \star)}$ \\
\hline \multicolumn{4}{|c|}{ Ammonium Nitrate } \\
\hline Plant Height & 0.987 & 0.034 & $\left.0.0000{ }^{(\star \star *}\right)$ \\
\hline No. of branches & 0.884 & 0.076 & $0.0000{ }^{(\star \star \star)}$ \\
\hline Fruiting Zone & 0.957 & 0.045 & $0.0000(\star \star \star)$ \\
\hline Seed yield/plant & 0.953 & 0.048 & $0.0000(\star \star \star)$ \\
\hline Seed yield/fed. & 0.953 & 0.048 & $0.0000(\star \star \star)$ \\
\hline Oil Percentage & -0.892 & 0.071 & $0.0000(* \star \star)$ \\
\hline
\end{tabular}


Table 4: Effect of three levels of Potassium-K $\left(\mathrm{g} / \mathrm{m}^{2}\right), \mathrm{GA}_{3}(\mathrm{~g} / \mathrm{ha})$ and their combination between them on plant height $(\mathrm{cm})$ of canola during four season 2014-18

\begin{tabular}{|c|c|c|c|c|}
\hline \multirow[t]{2}{*}{ Treatments } & \multicolumn{4}{|c|}{ Plant Height (cm) } \\
\hline & $2014 / 15$ & $2015 / 16$ & $2016 / 17$ & $2017 / 18$ \\
\hline T1 & 139.5 e & $141 d$ & $140.5 d$ & $140 \mathrm{e}$ \\
\hline T2 & 154.6 b & $153.8 \mathrm{e}$ & $155 \mathrm{c}$ & $154.8 \mathrm{f}$ \\
\hline T3 & $169.4 \mathrm{a}$ & $169.0 \mathrm{~cd}$ & $168.5 \mathrm{~b}$ & $170.0 \mathrm{ac}$ \\
\hline T4 & $178.3 \mathrm{~d}$ & $175.2 \mathrm{bc}$ & $177.2 \mathrm{a}$ & $176.5 \mathrm{bc}$ \\
\hline T5 & $152.1 \mathrm{~b}$ & 150.3 e & $151.8 \mathrm{c}$ & $151.9 \mathrm{f}$ \\
\hline T6 & $159.5 b$ & 156.3 e & $158.5 \mathrm{c}$ & 159.4 e \\
\hline T7 & 170.3 a & $168.9 \mathrm{~d}$ & $169.0 \mathrm{~b}$ & $171.3 \mathrm{a}$ \\
\hline T8 & $177.9 \mathrm{~d}$ & $176.4 \mathrm{~b}$ & 178.4 a & 176.9 b \\
\hline T9 & $179.5 \mathrm{~d}$ & $180.2 \mathrm{ab}$ & 180.5 a & $181.0 \mathrm{db}$ \\
\hline T10 & $183.4 \mathrm{~d}$ & $184.1 \mathrm{a}$ & 184.0 a & $184.9 \mathrm{~d}$ \\
\hline LSD 0.05 & 4.342 & 4.201 & 4.443 & 4.392 \\
\hline $\mathrm{F}$ & 81.913 & 99.79 & 86.782 & 101.34 \\
\hline$P$ & 0.0000 & 0.0000 & 0.0000 & 0.0000 \\
\hline
\end{tabular}


Table 5: Effect of three levels of Potassium-K $\left(\mathrm{g} / \mathrm{m}^{2}\right), \mathrm{GA}_{3}(\mathrm{~g} / \mathrm{ha})$ and their combination between them on number of branches/plant of canola during four season 2014-18

\begin{tabular}{|lllll|} 
Treatments & \multicolumn{4}{l}{ Number of branches/Plant } \\
\cline { 2 - 4 } & $2014 / 15$ & $2015 / 16$ & $2016 / 17$ & $2017 / 18$ \\
\hline T1 & $5.4 \mathrm{~b}$ & $5.2 \mathrm{~b}$ & $5.1 \mathrm{f}$ & $5.7 \mathrm{a}$ \\
\hline T3 & $5.7 \mathrm{bc}$ & $5.7 \mathrm{~b}$ & $5.8 \mathrm{ef}$ & $6.2 \mathrm{a}$ \\
\hline T4 & $7.1 \mathrm{ae}$ & $7.1 \mathrm{ce}$ & $7.0 \mathrm{~cd}$ & $7.6 \mathrm{dc}$ \\
\hline T5 & $7.5 \mathrm{ef}$ & $8.2 \mathrm{~d}$ & $7.6 \mathrm{bc}$ & $8.7 \mathrm{e}$ \\
\hline T6 & $6.1 \mathrm{c}$ & $5.9 \mathrm{ae}$ & $6.0 \mathrm{e}$ & $6.4 \mathrm{be}$ \\
\hline T7 & $6.7 \mathrm{a}$ & $6.6 \mathrm{~cd}$ & $6.8 \mathrm{~d}$ & $7.1 \mathrm{cb}$ \\
\hline T8 & $7.0 \mathrm{ae}$ & $7.2 \mathrm{ce}$ & $7.1 \mathrm{~cd}$ & $7.7 \mathrm{dc}$ \\
\hline T9 & $7.6 \mathrm{ef}$ & $7.9 \mathrm{de}$ & $7.7 \mathrm{bc}$ & $8.4 \mathrm{ad}$ \\
\hline T10 & $8.3 \mathrm{df}$ & $8.2 \mathrm{~d}$ & $8.2 \mathrm{ab}$ & $8.7 \mathrm{e}$ \\
\hline LSD 0.05 & $8.5 \mathrm{~d}$ & $8.6 \mathrm{~d}$ & $8.7 \mathrm{a}$ & $8.9 \mathrm{e}$ \\
\hline F & 0.503 & 0.524 & 0.407 & 0.556 \\
\hline P & 45.761 & 43.56 & 45.07 & 48.097 \\
\hline Val & 0.0000 & 0.0000 & 0.0000 & 0.0000 \\
\hline
\end{tabular}

Value within the column with the same letter are not significantly different (Tukey, HSD; p0.05), **P0.01 according to least significant difference (LSD) test. 
Table 6: Effect of three levels of Potassium-K $\left(\mathrm{g} / \mathrm{m}^{2}\right), \mathrm{GA}_{3}(\mathrm{~g} / \mathrm{ha})$ and their combination between themon Fruiting Zone length $(\mathrm{cm})$ of canola during four season 2014-18

\begin{tabular}{|c|c|c|c|c|}
\hline \multirow[t]{2}{*}{ Treatments } & \multicolumn{4}{|c|}{ Fruiting Zone length $(\mathrm{cm})$} \\
\hline & $2014 / 15$ & $2015 / 16$ & $2016 / 17$ & $2017 / 18$ \\
\hline T1 & $118.0 \mathrm{~h}$ & $120.5 d$ & $119.0 \mathrm{~h}$ & $121 \mathrm{~d}$ \\
\hline $\mathrm{T} 2$ & $123.2 \mathrm{~g}$ & $122.4 \mathrm{f}$ & $123.2 \mathrm{~g}$ & $123.4 \mathrm{f}$ \\
\hline T3 & 134.5 ef & $132.3 \mathrm{~cd}$ & 134.0 ef & $133.4 \mathrm{~cd}$ \\
\hline T4 & $140.0 \mathrm{~cd}$ & $139.5 \mathrm{bc}$ & $140.0 \mathrm{~cd}$ & $138.5 \mathrm{bc}$ \\
\hline T5 & $121.3 \mathrm{~g}$ & 118.5 ef & $122.3 \mathrm{~g}$ & 122.5 ef \\
\hline T6 & $131.0 \mathrm{f}$ & $128.4 \mathrm{~d}$ & $131.0 \mathrm{f}$ & $129.4 \mathrm{~d}$ \\
\hline T7 & $136.7 \mathrm{de}$ & $134.0 \mathrm{~cd}$ & $135.5 \mathrm{de}$ & $136.0 \mathrm{~cd}$ \\
\hline T8 & $143.5 \mathrm{bc}$ & $141.3 \mathrm{bc}$ & $141.5 \mathrm{bc}$ & $143.5 \mathrm{bc}$ \\
\hline T9 & $146 a b$ & $145.9 \mathrm{ab}$ & $148.0 \mathrm{ab}$ & $146.9 \mathrm{ab}$ \\
\hline T10 & $147.5 \mathrm{a}$ & 149.0 a & $147.5 \mathrm{a}$ & $148.5 \mathrm{a}$ \\
\hline LSD 0.05 & 3.507 & 3.231 & 3.403 & 3.306 \\
\hline $\mathrm{F}$ & 101.814 & 123.32 & 126.62 & 122.4 \\
\hline $\mathrm{P}$ & 0.0000 & 0.000 & 0.0000 & 0.000 \\
\hline
\end{tabular}

Value within the column with the same letter are not significantly different (Tukey, HSD; p0.05), **P0.01 according to least significant difference (LSD) test. 
Table 7: Effect of three levels of Potassium- $\mathrm{K}\left(\mathrm{g} / \mathrm{m}^{2}\right), \mathrm{GA}_{3}(\mathrm{~g} / \mathrm{ha})$ and their combination between them on Seed Yield /plant (g) of canola during four season 2014-18

\begin{tabular}{|c|c|c|c|c|}
\hline \multirow[t]{2}{*}{ Treatments } & \multicolumn{4}{|c|}{ Number of seed/ Plant (g) } \\
\hline & $2014 / 15$ & $2015 / 16$ & $2016 / 17$ & $2017 / 18$ \\
\hline T1 & $30.2 \mathrm{a}$ & $31.2 \mathrm{a}$ & $32.3 \mathrm{c}$ & $30.3 \mathrm{a}$ \\
\hline T2 & 32.4 ef & $32.4 \mathrm{ae}$ & $32.5 \mathrm{a}$ & $31.5 \mathrm{~g}$ \\
\hline T3 & $34.6 \mathrm{bc}$ & $34.6 \mathrm{~cd}$ & 37.4 ef & 36.4 be \\
\hline $\mathrm{T} 4$ & $36.0 \mathrm{bd}$ & $36.0 \mathrm{bc}$ & $38.1 \mathrm{dh}$ & $37.1 \mathrm{~cd}$ \\
\hline T5 & 33.9 abe & 33.9 ade & $34.4 \mathrm{a}$ & $33.4 \mathrm{~g}$ \\
\hline T6 & 33.5 be & $33.5 \mathrm{de}$ & $35.08 \mathrm{f}$ & $34.08 \mathrm{~b}$ \\
\hline T7 & $36.3 \mathrm{~cd}$ & $36.3 \mathrm{bc}$ & $37.2 \mathrm{dh}$ & $36.2 \mathrm{~cd}$ \\
\hline T8 & $37.8 \mathrm{~d}$ & $37.8 \mathrm{~b}$ & $38.4 \mathrm{bh}$ & $37.4 \mathrm{fc}$ \\
\hline T9 & $37.6 \mathrm{~d}$ & $37.6 \mathrm{~b}$ & $39.1 \mathrm{bg}$ & $38.1 \mathrm{fh}$ \\
\hline T10 & $40.0 \mathrm{f}$ & $40.0 \mathrm{f}$ & $41.7 \mathrm{~g}$ & $40.7 \mathrm{~h}$ \\
\hline LSD 0.05 & 1.184 & 1.172 & 1.195 & 1.245 \\
\hline $\mathrm{F}$ & 50.765 & 46.486 & 49.987 & 51.073 \\
\hline P & 0.0000 & 0.0000 & 0.0000 & 0.0000 \\
\hline
\end{tabular}

Value within the column with the same letter are not significantly different (Tukey, HSD; p0.05), **P0.01 according to least significant difference (LSD) test. 


\begin{tabular}{|c|c|c|c|c|}
\hline \multirow[t]{2}{*}{ Treatments } & \multicolumn{4}{|c|}{ Seed Yield } \\
\hline & $2014 / 15$ & $2015 / 16$ & $2016 / 17$ & $2017 / 18$ \\
\hline T1 & $685.3 \mathrm{e}$ & $657.7 \mathrm{~g}$ & $686.3 \mathrm{e}$ & $667.7 \mathrm{~g}$ \\
\hline T2 & $715.0 \mathrm{de}$ & $684.0 \mathrm{fg}$ & $716.0 \mathrm{de}$ & $694.0 \mathrm{fg}$ \\
\hline T3 & $781.0 \mathrm{c}$ & $762.2 \mathrm{de}$ & $782.0 \mathrm{c}$ & $762.2 \mathrm{de}$ \\
\hline T4 & 807.4 bc & $795.2 \mathrm{bcd}$ & 808.4 bc & $795.2 \mathrm{bcd}$ \\
\hline T5 & $717.2 \mathrm{de}$ & 729.0 ef & $718.2 \mathrm{de}$ & 727.0 ef \\
\hline T6 & $734.8 d$ & $751.4 \mathrm{de}$ & $735.8 \mathrm{~d}$ & $753.4 \mathrm{de}$ \\
\hline T7 & 800.8 bc & $785.6 \mathrm{~cd}$ & 801.8 bc & $788.6 \mathrm{~cd}$ \\
\hline T8 & 827.3 & 824.8 bc & 828.3 & 823.8 bc \\
\hline T9 & 829.5 & $835.7 b$ & 830.5 & 834.7 b \\
\hline T10 & 878.9 a & 881.3 a & 879.9 a & 883.3 a \\
\hline LSD 0.05 & 26.724 & 27.167 & 25.574 & 26.543 \\
\hline $\mathrm{F}$ & 44.576 & 49.903 & 48.765 & 51.273 \\
\hline$P$ & 0.0000 & 0.0000 & 0.0000 & 0.0000 \\
\hline
\end{tabular}




\begin{tabular}{|c|c|c|c|c|}
\hline \multirow[t]{2}{*}{ Treatments } & \multicolumn{4}{|c|}{ Seed Oil Percentag } \\
\hline & $2014 / 15$ & $2015 / 16$ & $2016 / 17$ & 2017/18 \\
\hline T1 & $41.09 \mathrm{bc}$ & $41.65 \mathrm{ab}$ & $42.36 \mathrm{a}$ & $42.50 \mathrm{c}$ \\
\hline T2 & $42.53 \mathrm{bc}$ & $41.53 \mathrm{ab}$ & $42.35 \mathrm{a}$ & $43.35 \mathrm{c}$ \\
\hline T3 & $42.96 \mathrm{bc}$ & $42.94 \mathrm{ab}$ & 42.89 a & $43.05 \mathrm{c}$ \\
\hline T4 & $42.51 \mathrm{c}$ & $41.51 \mathrm{~b}$ & $42.55 \mathrm{cda}$ & $42.59 \mathrm{cbe}$ \\
\hline T5 & $42.79 \mathrm{bc}$ & $42.80 \mathrm{ab}$ & $42.69 \mathrm{~cd}$ & 42.90 be \\
\hline T6 & $42.87 \mathrm{ab}$ & $42.86 \mathrm{ac}$ & 42.95 be & $42.99 \mathrm{ad}$ \\
\hline T7 & $43.17 \mathrm{a}$ & $43.17 \mathrm{c}$ & $43.02 \mathrm{e}$ & $43.08 \mathrm{a}$ \\
\hline T8 & $42.64 \mathrm{bc}$ & $42.79 a b$ & $42.48 \mathrm{de}$ & $42.60 \mathrm{bc}$ \\
\hline T9 & $42.66 \mathrm{bc}$ & $42.87 \mathrm{ab}$ & $42.74 \mathrm{bc}$ & $42.84 \mathrm{de}$ \\
\hline T10 & $44.56 \mathrm{bc}$ & $43.85 a b$ & $45.54 \mathrm{~cd}$ & 44.69 be \\
\hline LSD 0.05 & 0.1567 & 0.1893 & 0.2101 & 0.2043 \\
\hline$F$ & 7.753 & 9.873 & 16.874 & 17.765 \\
\hline $\mathrm{P}$ & 0.0000 & 0.0000 & 0.0000 & 0.0000 \\
\hline
\end{tabular}

